\title{
A encenação na fotografia - montando cenas e contando histórias
}

\author{
Osmar Gonçalves dos Reis Filho' \\ https://orcid.org/0000-0002-3986-9008 \\ Isabelle Freire de Morais' \\ https://orcid.org/0000-0001-7111-7052 \\ I - UFC \\ Fortaleza (CE), Brasil
}

Resumo: Neste trabalho buscamos compreender, historicamente, o que seria e como tem sido construída a encenação na linguagem fotográfica. Partindo das reflexões de Fontcuberta, Soulages e Rouillé, refletiremos sobre categorias como performance, manipulação, ficção e verdade. Trata-se de mostrar que, apesar do que advoga o senso comum e defendem certas teorias ontológicas da fotografia (em especial Barthes, mas também Kracauer, Krauss, entre outros), a encenação sempre fez parte do processo fotográfico e hoje, num momento em que ela é praticada de forma mais aberta e consciente, um novo campo de experimentações se abre à fotografia, novas formas de ver e mostrar permeadas por um desejo de fabulação, uma vontade de inventar mundos e contar histórias.

Palavras-Chave: fotografia; encenação; manipulação; ficção; verdade.

Abstract: The staging in the photography - assembling scenes and telling stories - This paper aims to understand historically what would be and how it has been constructed the staging in the photographic language. Based on the thoughts of Fontcuberta, Soulages and Rouillé, we reflect on categories such as performance, manipulation, fiction and truth. This is to show that, in spite of what common sense advocates and certain ontological theories of photography defend (especially Barthes, but also Kracauer, Krauss, among others), staging has always been part of the photographic process and today, at a time in which it is practiced more openly and consciously, a new field of experimentation opens to photography, new ways of seeing and show permeated by a desire to fable, a willingness to invent worlds and tell stories.

Keywords: photography; staging; manipulation; fiction; truth. 


\section{Introdução}

São conhecidos os estudos sobre o papel constitutivo da encenação nos processos formativos de inúmeras artes e linguagens, seja no teatro, na performance, nas artes plásticas ou no cinema. No belíssimo O cinema e a encenação, por exemplo, Jacques Aumont afirma que, na prática cinematográfica, "ela está em toda parte, nada se pode imaginar sem ela" (2006, p. 10). Por que, então, a relativa ausência de trabalhos sobre a encenação na história e na teoria da fotografia? Será que ela não se implica com o ato fotográfico? Defendemos que sim! Arriscamos dizer, inclusive, que a encenação se constituiria numa segunda natureza do dispositivo fotográfico, dele proscrita em sua origem ${ }^{1}$, que o relacionamento com a linguagem teatral ajudou a construir, mas que no próprio dispositivo vai assumir, ao longo de sua história, contornos cada vez mais específicos. E complexos.

Nosso olhar volta-se aqui para além de um desejo de reconstituição histórica. Tampouco há a intenção de propor definições para a noção de encenação na linguagem fotográfica. Não é essa nossa incumbência. Por hora, e em função da proposta deste trabalho, sublinharemos nela a noção de gesto criativo, de invenção, de exercício que organiza a ilusão e que amplia o protocolo do fotografável. Trata-se de uma tentativa de entender como a encenação, esse gesto originário do teatro, deixando de remeter incessantemente a ele, embora não o exclua por completo, adquiriu sentido na linguagem fotográfica. Para isso, destacaremos seus terrenos mais férteis no entrelaçamento com o teatral e alguns de seus domínios particulares, em sua época pretérita.

Falar da encenação, a propósito da fotografia, é falar de um conceito que possui cada vez mais aceitação em seus ciclos pragmáticos, mas que ainda não é tratado como central. Enfrenta resistências: "essas crenças comuns e clichês em torno do realismo e da perfeição técnica continua impondo entre os leigos e entre os néscios os modos como deve parecer uma fotografia" (FONTCUBERTA, 2010, p. 72).

De onde vêm essas crenças? A gênese tecnológica do procedimento fotográfico é um dos argumentos que as sustentam: como projeção de uma cena de forma global em uma superfície fotossensível de forma mecânica e automática produziria análogos confiáveis do real e, por isso, considerada não objeto de intervenções. Fontcuberta nos dá um panorama geral sobre o contexto histórico em que surge essa construção ideológica:

Como é sabido, todos os elementos que intervém no processo fotoquímico da fotografia eram conhecidos com muita anterioridade à data de divulgação do daguerreótipo: Aristóteles menciona os princípios óticos da câmara escura; os alquimistas árabes estavam familiarizados com as propriedades fotossensíveis

1 Notarial e especulativa, de registro e de ficção: a fotografia é ambígua desde sua origem. A proeminência da cultura tecnológica e de seus valores acaba dando destaque apenas a uma dessas facetas: a documental. Contudo, apesar da tirania desse modelo, sempre houve movimentos de resistência: é na sua contracorrente que a fotografia irá evoluir. Serão as tentativas em torno dessa segunda natureza fotográfica, em suas questões de ordem técnica, estética, poética e metalingüísticas (que passamos nesse trabalho a chamar, também, de encenação) que irão impulsionar o desenvolvimento da fotografia (FONTCUBERTA, 2010). 
dos halitas de prata. No entanto, o que conhecemos usualmente como fotografia só se cristaliza no início do século XIX porque é justamente nesse momento que a cultura tecnocientífica do positivismo requer um procedimento que certifique a observação empírica da natureza. A câmera aparece, portanto, ligada às noções de objetividade, verdade, identidade, cor, documento, arquivo, etc. A câmera será um instrumento a serviço da industrialização, a serviço do colonialismo, a serviço das incipientes disciplinas de controle e vigilância. (FONTCUBERTA, 2010, p. 63)

"Essência, imperativo tecnológico e fatalidade se coligaram para infundir nesses depósitos de sais de prata a sensação de verdade" (FONTCUBERTA, 2012, p. 186). O propósito de proporcionar "verdades visuais" sobre o mundo torna-se, então, hegemônico na fotografia e qualquer reticência quanto a esse seu caráter equivaleria a um sacrilégio. Embora o fim da modernidade tenha transformado a verdade em uma categoria pouco operativa e apesar de há muito ter caído por terra o mito da veracidade, da verossimilhança fotográfica, "ainda hoje, tanto no âmbito cotidiano, quanto no contexto estrito da criação artística, a fotografia aparece como uma tecnologia a serviço da verdade" (FONTCUBERTA, 2010, p. 13).

Tais afirmativas nos apresentam algumas questões: por que insistimos em acreditar nas imagens fotográficas? Talvez, como o próprio Fontcuberta nos sugere, por estarmos imersos em um momento de transição, em que os novos modelos ainda não estariam totalmente claros: seria natural, sintomático dessa confusão que vivenciamos, nos apegarmos à estabilidade que a crença na vertente documental da fotografia proporciona.

Por que discutir encenação na fotografia quando a era digital insinua desconstruir definitivamente o mito documental? Fontcuberta continua nos oferecendo pistas sobre isso. Segundo ele, a introdução de melhoramentos tecnológicos ainda não teria afetado substancialmente a natureza da fotografia: "nem mesmo a metamorfose do grão de prata em pixel é crucial, desde que a câmera como dispositivo de captação intervenha na gênese do processo fotográfico" (FONTCUBERTA, 2010, p. 101). A câmera, prossegue argumentando, ainda garantiria ao processo muito do mito de indicialidade e de rastro e, na pós-produção fotográfica, o computador, poderoso laboratório eletrônico, ainda manteria ilesas certas convenções. Do rastro à impressão digital, a fotografia, esse "signo inocente", continuaria a encobrir uma carga de artifícios carregados de propósito e de história. Camuflaria mecanismos culturais e ideológicos que afetariam nossa compreensão sobre o real: "mente sempre, mente por instinto, mente porque sua natureza não lhe permite fazer outra coisa" (Ibidem, p. 13). Falar, ainda hoje, sobre encenação na fotografia nos ajudaria a entender não só como essa "mentira" vem se constituindo, ao longo da sua história, mas a que propósitos serviu e ainda se submete.

\section{Um olhar sobre a encenação}

Começaremos nossa reflexão sobre encenação fotográfica pela análise etimológica da palavra fotografia. Mesmo correndo o risco de parecer clichê, seguiremos nessa via. 
Ao batizar o novo invento como escrita da luz, Fox Talbot teria demonstrado não conhecer com profundidade o idioma grego. Escrita das aparências seria a denominação mais adequada para o novo procedimento:

O prefixo foto deriva de fos, que significa luz, porém teria sido mais correto soletrar "fàos". Dessa forma, estaríamos mais próximos de faiein e fainein, termos que deveriam ser traduzidos como "aparecer" e que originaram palavras como fantasma, fantasia [...] e, por extensão, espectros, ilusões e aparições (FONTCUBERTA, 2010, p. 111).

Vemos que a própria origem do termo já carrega em si um rastro de ligação com a encenação. E fato é que a encenação existe no ato fotográfico desde sua gênese: naquele período ainda motivada por questões técnicas, mas aliando-se já, fortemente, com o teatral. Não são poucos os exemplos disso. Muitos foram os modelos de imagem encenada que ajudaram a escrever a história e a identidade da fotografia. Vejamos alguns.

A construção de cenas fotográficas teria origem na fotografia dos tableaux vivants. Reproduzindo pinturas famosas, eventos mitológicos, arquetípicos ou históricos, os tableaux vivant ganham extrema popularidade como forma de entretenimento no século XIX. Como passatempo divertido, torna-se uma atração encontrada tanto no contexto dos encontros sociais mais populares e informais como nos ricos salões da sociedade da época. Enquadrando essas cenas estavam os fotógrafos: compunham esses primeiros clichês não só com um olhar pictural mas, também, extremamente teatral. Para Dobal, a introdução da fotografia na prática dos tableaux vivant, que ganha fôlego principalmente na Inglaterra daquele período, não se restringiria apenas ao mero registro de uma performance: "logo os fotógrafos se tornariam diretores da encenação para obter o máximo de expressividade na cena" (DOBAL, 2013, p. 82).

Muitos anos depois, Barthes (1996, p. 54) afirmará: "a fotografia é um tipo de teatro primitivo, uma espécie de tableaux vivant". E ao comentar a prática dos tableaux ingleses de sua época, Baudelaire também faz declarações clarividentes a respeito de certas afinidades, para nossa pesquisa, importantes.

Uma loucura, um fanatismo extraordinário tomou de assalto a todos os novos adoradores do sol. Estranhas abominações acontecem. Ao agrupar homens e mulheres engraçados, vestidos como açougueiros e lavadeiras para o carnaval, e implorarem a esses heróis a manter, por quanto tempo for necessário para o serviço, um sorriso forçado e engessado para a ocasião, lisonjeiam-se por retratar cenas trágicas ou gloriosas da história antiga. Algum escritor democrático deve ter visto nisso, uma forma barata de espalhar entre as pessoas o gosto pela história e pela pintura e, assim procedendo, cometem um duplo sacrilégio ao insultar tanto a divina pintura quanto a sublime arte do ator. (Baudelaire citado por Lacoue-Labarthe, 114, apud ERTEM, 2006, p. 56, tradução nossa). 
Desconsideremos o tom exacerbado da fala de Baudelaire. Conhecemos sua oposição ferrenha e resistência tenaz ao procedimento fotográfico. Para criticá-lo, ele sempre optou por posições extremadas. Interessa-nos algo mais nessas suas declarações: o argumento que utiliza para apontar um possível caráter artificial da fotografia. Ele o faz reconhecendo uma conexão entre fotografia e teatralidade: Baudelaire concebe a fotografia mais como teatro do que como reprodução da realidade embora, a sua maneira polêmica, a rebaixe a um mau teatro.

"No gesto fotográfico prevaleceu uma intenção descritiva" (FONTCUBERTA, 2010, p. 106). É fato. O interessante é constatar que, desde os primeiros disparos "essa ânsia descritiva se valeu muito freqüentemente de "trapaça'" (Idem, 2012, p. 106). E mais curioso ainda é saber de onde ela partiu. Conta-nos Fontcuberta que Daguerre era, também, um homem do teatro. Procedia do mundo do espetáculo e do entretenimento. Como cenógrafo, trabalhara no Théâtre Ambigu-Comique localizado no Boulevard du Temple: lugar apelidado de Alameda do Crime, onde proliferavam numerosos teatros e lugares de má reputação. É uma vista deste local, captada por ele de um janela localizada no apartamento onde residia que, curiosamente, seria considerada "a primeira imagem fotográfica da qual se tem notícia em que aparece um ser humano, a primeira tentativa, portanto, de retrato, e a primeira simulação de instantaneidade" (Ibidem, p. 108). Isto porque, para conseguir registrá-la, Daguerre recorre a um "estratagema de encenação" já que, mesmo expondo sua chapa de prata em um horário de grande movimentação, obtém um primeiro resultado inesperado: aquela via onde a vida era pulsante e intensa aparece vazia. Onde estariam as pessoas, os cavalos, as carroças? (Figura 1).

Requerendo tempos de exposição absurdamente prolongados, o daguerreótipo fracassa na tentativa de registrar o dinamismo daquela famosa rua. Serão os recursos obtidos em sua experiência teatral que ajudarão Daguerre a construir essa emblemática primeira imagem da figura humana. Vejamos a Figura 2. Além da mudança na luz, direção das sombras e contrastes, percebe-se nela um outro detalhe: no canto inferior esquerdo delineia-se a silhueta de dois personagens. Sim, personagens. Embora não representados por atores profissionais mas, possivelmente, por figurantes ocasionais contratados por Daguerre a troco de uma gorjeta ou, talvez, por seus próprios assistentes. Atuando como encenador, ele os instrui a simularem uma cena: um engraxate, em plena atividade, atendendo seu cliente que encontra-se em pé. Ambos aguardam em posição estática o tempo necessário para fixar "aquele contraponto humano no vazio metafísico daquela cidade espectral" (FONTCUBERTA, 2010, p. 109). 

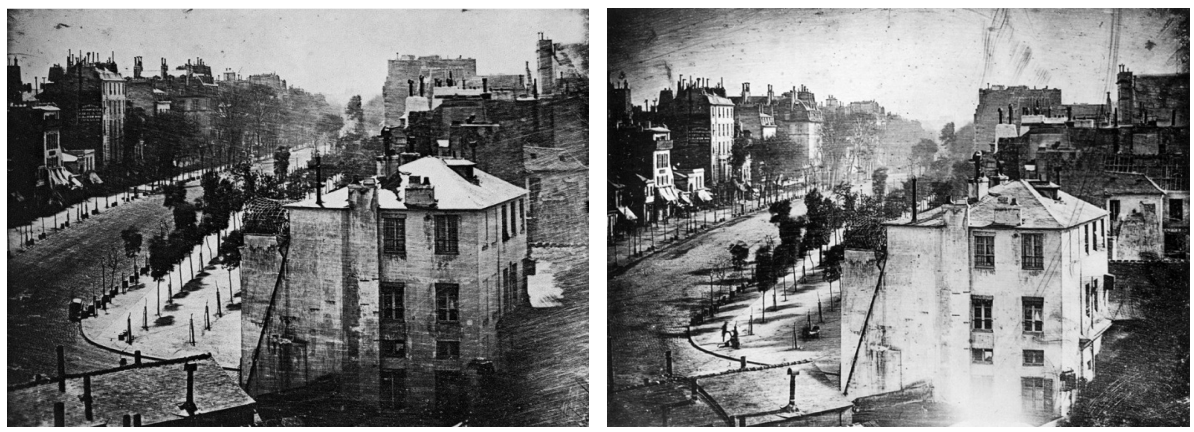

Figs. 1 e 2. Vista Del Boulevard du Temp, 1838.

Fonte: http://veintidosdeabril.tumblr.com/post/71431994770/louis-daguerre-vista-del-boulevard-du-temple

Por convenção histórica, o nascimento da fotografia costuma ser associado ao reconhecimento dado às experiências realizadas por Louis Daguerre em parceria com Nicéphore Niépce. Anunciada publicamente em cerimônia conjunta pela Academia de Ciências de Paris e Academia de Belas Artes, em 1839, a invenção do daguerreótipo inaugura oficialmente o advento da fotografia no século XIX. No entanto, segundo Annateresa Fabris (2008), tal anúncio é imediatamente questionado por outros inventores contemporâneos que reivindicam, também, sua paternidade. Contestando os rumores oficiais, eles afirmam já terem conseguido fixar imagens criadas pela ação da luz através de processos fotográficos diferenciados e até mesmo anteriores à daguerreotipia, que registrava as imagens em chapas de metal.

Dentre eles, na Inglaterra, Fox Talbot se destaca por sua técnica denominada calotipia. O processo, só patenteado por seu criador em 1840, cujas pesquisas e desenvolvimento antecederiam ao de Daguerre, consistia na obtenção de cópias múltiplas de imagens em negativo sobre papel. Já na própria França, Hyppolyte Bayard teria conseguido, desde 1837, desenvolver um método próprio de impressão de imagens: um positivo direto e único em um suporte de papel.

Embaraços históricos à parte, e independente da qualidade da reprodução que cada técnica oferecia e do uso a que cada uma se destinou, interessa-nos, particularmente, como esses acontecimentos repercutiram na vida de Bayard. Inconformado por não ter seu mérito como inventor reconhecido, em 1840, ele se autorrepresenta em uma fotografia intitulada Autorretrato de um Homem Afogado.

$\mathrm{Na}$ imagem, ele aparece sem camisa, coberto por uma espécie de toalha, de olhos fechados como que desfalecido, simulando um suposto afogamento. Em atitude extremada, é movido por uma grande frustração: a desconsideração, por parte das autoridades francesas, de suas pesquisas e de seu nome no crédito final dado à invenção da fotografia. Teria surgido, assim, o primeiro autorretrato fotográfico? Sabe-se, contudo, amparados nas afirmações de Dubois, ser a tradição da autorretratação extremamente desenvolvida 
na fotografia: "não existe praticamente um fotógrafo importante que não tenha voltado contra ele sua caixinha negra" (DUBOIS, 1993, p. 128).

A crescente demanda da sociedade industrial por imagens cada vez mais nítidas, detalhadas, com funções informativas e ligadas a uma possível representação fiel da realidade confirma o sucesso do procedimento de Daguerre e mantém sua hegemonia nos primeiros anos da fotografia. No entanto, Benjamin (1987) se refere a outro período da fotografia ocorrido no primeiro decênio após sua descoberta, anterior a sua fase de industrialização quando entraria em declínio. Período primitivo, de apogeu e de grandeza aurática dos primeiros clichês fotográficos. Citado por Benjamin, Bayard faria parte dessa primeira geração de fotógrafos que buscavam explorar potencialidades artísticas em suas criações. Utilizam-se, para isso, de técnicas como o desfocado e a exploração da expressividade cênica dos retratados induzida pela pose: sua dramaticidade fisionômica é acentuada em razão da imobilidade gerada pelas longas exposições. Tais procedimentos teriam conseguido proporcionar um valor mágico e aurático ao processo fotográfico em sua primeira fase, diferindo-o daquilo que Benjamin chamava de "nitidez insólita dos primeiros daguerreótipos" (1987, p. 95).

O fato é que, como forma de protesto, Bayard encena e retrata sua própria morte numa configuração inteiramente performática de construção de imagem: observada tanto na maneira como usa o aparato fotográfico, como seu próprio corpo. Orientando-se de forma contrária à lógica comercial, empregando processo fotográfico diferenciado e minoritário, assumindo uma postura artística com finalidades estéticas diversas das ligadas à representação mimética, à referencialidade, e usando seu próprio corpo, parcialmente nu, como objeto de uma manifestação política, ele transforma a fotografia. Da designação para a expressão².

\section{"A verdade está no truque": performatividade e intervenção no processo fotográfico}

O autorretrato de Bayard oferece-nos um indício exemplar de como a performatividade afetou a produção fotográfica desde suas origens. Nele, autorrepresentação e essência performática se entrelaçam e se relacionam intimamente: resultando na produção de uma ação que acontece no próprio ato da construção fotográfica e que busca romper com formas, estéticas, padrões. Essa ideia de ação, associada à fotografia, estaria relacionada com uma representação não no sentido mimético mas compreendida com

2 Para Rouillé (2009), o regime da designação tornaria opacas todas as infinitas mediações que sofrem as imagens. Sem Ihe atribuir uma autoria, nem um processo de intervenção em sua captação e registro, as trataria apenas como puros vetores de informação das coisas e estado das coisas. No regime de expressão a fotografia deixaria de ser a representação passiva de um mundo preexistente e de um referente que adere. Ela passaria a levar em consideração o que o autor chama de "acontecimentos incorporais": "que intervêm na fronteira das coisas e dos enunciados (textuais e icônicos); que sobrevêm às coisas e aos corpos e que não existem fora dos enunciados que os exprimem" (ROUILLÉ, 2009, p. 136). 
uma apresentação: "imagem que apresenta a apresentação (...) que realiza a performance renunciando a uma conexão estável e definitiva entre ela e o referente" (ERTEM, 2006, p. 89, tradução nossa), revelando infinitas possibilidades de expressar a subjetividade humana, complementa. Bayard revela-se presente, constrói relações e se enuncia performaticamente. Desloca a fotografia do terreno da fruição para o da intervenção: intenciona questionar, transformar, atingir um objetivo específico. Para isso, trabalha simbólica e ritualisticamente suas questões e utiliza a fotografia para se autorrepresentar em um evento ficcional construído e realizado fora da caixa cênica, destinada, tradicionalmente, às encenações.

Da encenação explorada nos autorretratos, mais engajada com o teatral, a vemos enveredar, na fotografia, por um outro caminho à procura de um status de arte que lhe era negado: o pictorialismo. Será ele o primeiro grande movimento de oposição à pratica comercial que se tornava hegemônica e submetia a fotografia, estética e economicamente, à lógica do capitalismo industrial. A pintura inspira esse empenho. Mobilizados pelo papel sagrado que era atribuído, na época, à mão, e ainda incapazes de vislumbrarem uma alternativa tecnológica para a arte, os fotógrafos assumem a pintura para "servir de referência às necessidades internas da fotografia artística e para sustentar o processo de sua autonomização" (ROUILLÉ, 2009, p. 240). Defendendo a manipulação no processo fotográfico, a humanização da objetiva e a atenuação das características mecânicas do dispositivo, a fotografia pictoralista encena. Encena ao opor-se a qualquer entrave à expressão da individualidade do fotógrafo e à promoção de seu trabalho como obra de arte.

Inovações são experimentadas em variados procedimentos mistos de intervenção que, ao hibridizar mão e máquina, intentavam "frear todos os automatismos fundadores da reprodutibilidade e da multiplicidade fotográficas e introduzir a interpretação em todas as etapas que conduzem da coisa ao clichê e, depois a prova" (ROUILLÉ, 2009, p. 260). No período entreguerras, no entanto, a aliança pictorialista entre a mão e o aparelho passa a ser questionada com a emergência de um novo movimento intitulado nova objetividade. A retórica desse movimento defendia uma arte especificamente fotográfica em que a máquina adquiriria soberania artística: como instrumento de conhecimento intuitivo ela era capaz de gerar novas formas na criação e conseguir resultados que não poderiam ser obtidos por outros meios. Estabelece-se aqui então uma nova aliança: a aliança ótica e mecânica entre a máquina e as coisas, supostamente afastada de quaisquer intervenções humanas e que traduziriam as exigências modernistas de objetividade e realismo.

Instaura-se uma nova visibilidade fotográfica: a da superfície das coisas, que pretendese puramente mecânica, puramente fotográfica e que "fixa para si, como projeto, restituir a magia da realidade com exatidão" (ROUILLÉ, 2009, p. 265). Neste contexto, a objetiva é máquina de ver que suplanta os limites do olho. Já o fotógrafo, acredita expressar seu sentimento a respeito do mundo "não como a descrição de estados interiores do ser, mas como transcendência da visão individual" (FABRIS, 2011, p. 49). A pretensa neutralidade da nova objetividade esconde, contudo, um outro tipo de encenação na fotografia: aquela 
que implica na manipulação do mundo por meio do aparelho fotográfico, que tem a superfície material das coisas como única e completa realidade e é cega aos fenômenos sociais e humanos. Sua visibilidade que glorifica o universo da máquina, esconde jogos de poder ligados, principalmente, à organização social do trabalho3 ${ }^{3}$

Um parêntese: a oposição nova objetividade versus pictorialismo é exemplar para compreendermos uma polarização que marca a história da fotografia - fotografia direta versus fotografia manipulada, ou práticas documentais versus práticas artísticas. A fotografia direta, grosso modo, é associada à técnica fotográfica ortodoxa e a um conjunto de procedimentos considerados genuínos do meio. Implicaria na imprevisibilidade e espontaneidade da ação e do registro, no respeito às características óticas e mecânicas do dispositivo etc. Já a fotografia manipulada suporia controle, planejamento e intervenção por parte do fotógrafo, considerando legítima a inclusão de qualquer recurso ou efeito que lhe acentuasse a expressão. Ocorre que uma sanção moral passa a ser atribuída ao ato de manipular e atinge a construção fotográfica em suas diversas tentativas de se afastar de um restrito programa realista esquecendo-se que "não existe um ato humano que não implique manipulação" (FONTCUBERTA, 2010, p.104).

Manipular é um termo que carrega vários significados. Nos dicionários encontramos alguns: preparar com as mãos, pôr em movimento, engendrar, forjar, controlar, dominar. Segundo Fontcuberta, sua acepção como algo reprovável adquire maior evidência quando velhos marxistas, filósofos e estudiosos de comunicação de massas desenvolvem um discurso crítico em resposta ao poder capitalista que se tornava hegemônico, nos inícios do século XX. Nesse discurso, o conceito de manipulação passa a ocupar um lugar privilegiado e a ser comumente associado a "atuar em benefício próprio e em prejuízo de outros e, além disso, em fazê-lo com deliberação e traição" (FONTCUBERTA, 2010, p. 82). Excessos, floreios, tergiversação: a ação de manipular na fotografia sempre carregou conotações pejorativas. Para o autor, merece ser reabilitada:

Realizar uma fotografia requer adotar decisões e dotá-las de um conteúdo expressivo, ou seja, construir uma retórica. A escolha de uma entre diversas possibilidades representa uma pequena dose de "manipulação": enquadrar é uma manipulação, enfocar é uma manipulação, selecionar o momento do disparo é uma manipulação... A soma de todos esses passos se concretiza na imagem resultante, uma "manipulação" sem paliativos. Criar equivale a manipular e o próprio termo "fotografia manipulada" constitui uma flagrante tautologia. [...] Definitivamente, a manipulação se apresenta como uma condição sine qua non da criação (FONTCUBERTA, 2010, p. 84).

3 Rouillé é esclarecedor sobre isso: "a fotografia da Nova Objetividade incorpora-se à industria pelo que mostra, por seu caráter mecânico, sua maneira de transfigurar qualquer coisa em objeto industrial, e por sua orientação estética, que faz da técnica o fundamento da beleza. A preferência pela indústria confirma-se igualmente naquilo que a Nova Objetividade oculta, naquilo que ela deixa à sombra: a exploração e as lutas sociais, a vida e a subjetividade dos homens. (ROUILLÉ, 2009, p. 268). 


\section{O espelho de Alice: a fotografia como dispositivo de fabulação}

Outro parêntese: a ficção, dentro da tradição hegemônica do realismo na fotografia, se constituiria uma espécie de desvio do meio: prática comumente ocultada e marginalizada. Em francês, a palavra ficção remeteria a dois sentidos: "ao que é mentiroso e falso e ao que é imaginado e inventado, sem vontade de enganar"4 (SOULAGES, 2010, p. 115). A tradição documental impõe ao termo o sentido de uma construção menor pertencente à esfera do enganoso, não permitindo pensar o fotográfico e agir fotograficamente nesse sentido. A necessidade ontológica do homem de obter provas inequívocas de sua existência e do real reforçariam essa rejeição. Pensar o fictício na fotografia, entretanto, é reconhecer sua capacidade de inventar mundos: "rearranjos materiais dos signos e das imagens, das relações entre o que se vê e o que se diz, entre o que se faz e o que se pode fazer" (RANCIÉRE, 2005, p. 59). Ficção como espaço para o lúdico, para o jogo, terreno de experimentação, de experiência e de liberdade para a atuação do homem contemporâneo. Homo ludens como sugere Flusser: um jogador que, vivendo em uma sociedade programada, teria que jogar contra o programa, a fim de esgotá-lo e superá-lo.

Manipulação, jogo, ficcionalização, encenação. Fronteiras entre a representação e a realidade. Sinônimos. Escolhemos encenação: palavra múltipla. A fotografia alegórica primitiva, os exageros subjetivos do pictorialismo, os excessos óticos do absolutamente nítido da nova objetividade e outros procedimentos observados nas vanguardas históricas do século XX confirmam a variabilidade e complexidade daquilo que chamamos de encenação na fotografia nas diferentes concepções de realidade em que se situam. Mesmo no modernismo, quando é rejeitada, a encenação se manifesta e se traduz em ficções documentais: "as fotografias-documento do começo ao fim são construídas, convencionais e mediatas" (ROUILLÉ, 2009, p. 62). Aparentam realismo, exatidão e verdade graças a um sistema de crenças e convicções inseparáveis de um intenso processo de construção intelectual e ideológico. Alerta-nos sobre isso Flusser, em sua Filosofia da Caixa Preta: "a aparente objetividade das imagens técnicas é ilusória, pois na realidade são tão simbólicas quanto o são todas as imagens [...] o que vemos ao contemplá-las não é 'o mundo' mas determinados conceitos relativos ao mundo' (2011, p. 31).

Nas últimas décadas do século XX a encenação é retomada com empenho: é mecanismo antimoderno de desconstrução e crítica ao legado imagético documental. Em suas estratégias de encenação, desde as mais prosaicas até as engendradas em suas ramificações com a arte contemporânea, a fotografia busca um retorno a si mesma. Retorno que passa, inevitavelmente, "pela aceitação e pelo desejo da ficção" (SOULAGES, 2010, p. 112).

4 Rancière também reflete sobre a necessidade de separação da ideia de ficção da noção de mentira: "fingir não é propor engodos, porém elaborar estruturas inteligíveis (...) o real precisa ser ficcionalizado para ser pensado [...] A ficção na era estética definiu modelos de conexão entre apresentação dos fatos e formas de inteligibilidade que tornam indefinida a fronteira entre razão dos fatos e razão da ficção (...) Escrever a história e escrever histórias pertencem a um mesmo regime de verdade. (RANCIÈRE, 2005, p. 53, 58). 
Em nossos tempos, ela infiltra-se na fotografia como experiência sensorial e a transforma em um espaço repleto de diferentes propostas conceituais, estéticas e antiestéticas: palco para o performativo, o biográfico, o cênico, o simbólico.

\begin{abstract}
A fotografia, em sua origem, teve que se aproximar da ficção para demonstrar sua natureza artística e seu objetivo prioritário consistia em traduzir os fatos em sopros de imaginação. Hoje, ao contrário, o real se funde com a ficção e a fotografia pode fechar um ciclo: devolver o ilusório e o prodigioso às tramas do simbólico que costumam ser finalmente as verdadeiras caldeiras onde se cozinha a interpretação de nossa experiência, isto é, a produção de realidade. (FONTCUBERTA, 2010, p. 124).
\end{abstract}

Isso se deixa ver nas obras de inúmeros fotógrafos e artistas contemporâneos, como Cindy Sherman, Jeff Wall, Duane Michals, Jorge Molder, Philipp-Lorca Dicorcia, Erwin Olaf, Marcos Lopes, Barbara Wagner, entre outros. Sem dúvida, há uma linha de força bastante representativa na fotografia contemporânea na qual o fotógrafo parece pensar o espaço da representação como uma espécie de palco de teatro sobre o qual modelos vêm atuar. Nesse universo marcado pela estilização teatral da imagem, o registro ou a captação deixam de ter a primazia no processo fotográfico, já que a fotografia é toda ela programada e concebida previamente.

Para o fotógrafo, não se trata mais de preparar armadilhas ao acaso, de produzir imagens de captura, conforme a feliz expressão de Rouillé, mas de traduzir a execução de uma pose. Numa palavra, o fotógrafo não "estiliza" mais pela originalidade do olhar, mas pela concepção de uma cena e/ou pela tradução visual de uma história.

Antes condenada, a construção passa agora a ser parte integrante do processo de produção de imagens. Os fotógrafos contemporâneos não se sentem mais acanhados em dirigir a cena ou interferir na imagem, em mudar objetos de lugar ou conduzir seus personagens. Mesmo no campo da prática documental, fotógrafos como Fred Merz, Maya Goded e Alexandre Severo armam cuidadosamente suas imagens, dirigem e ensaiam com os retratados, convidando-os a encenar a si mesmos. O premiado fotógrafo argentino, Alejandro Chaskielberg, é bastante claro ao dizer que constrói seus ensaios "na borda da realidade, criando roteiros fictícios com pessoas e situações reais, tentando forçar os limites da fotografia documental"(apud DOBAL; REIS FILHO, 2013, p. 86). O resultado são imagens fortemente ambíguas, envoltas numa atmosfera de magia e mistério, imagens que nos apresentam uma mescla imaginativa de fatos e fabulação, que oscilam entre o sonho e o documento, a realidade e a ficção. 


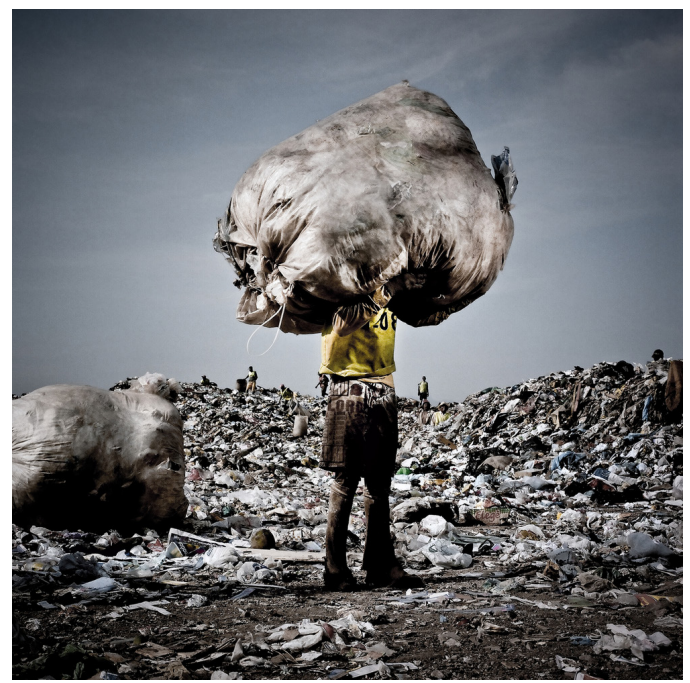

Fig. 3. Fred Merz. Catadores, Jardim Gramacho (RJ), Brasil. 2010. Fonte: https://www.lundi13.ch/fred-merz/

Para Michel Poivert, esse seria o ponto nevrálgico dessa fotografia encenada ou teatralizada: essa espécie de indiscernibilidade que ela produz, esse duplo regime, paradoxal, do verdadeiro e do falso. Nas palavras do historiador da arte e da fotografia francês:

Esta correlação entre encenação e fotografia produz um híbrido que, em sua instabilidade ao mesmo tempo de imagem mental (imitativa, simbólica ou ficcional) e factual (seu médium concebido como "transparente"), dificulta a compreensão do espectador. (POIVERT, 2015, p. 112-113)

Isto porque a encenação não necessariamente elimina a impressão de verdade, a sensação persistente de realismo, produzida, segundo Poivert, pela "transparência" do médium, isto é, pela "operação de registro naquilo que ela contém de automatização" (2015, p. 105). Em outras palavras, a expectativa de realidade, fortemente entrelaçada na fotografia ao automatismo da câmera e às noções de rastro e vestígio, dá margem nessas imagens a uma forte ambigüidade e acaba intensificando a tensão entre o real e o imaginado, o factual e o inventado. De acordo com Poivert, a fotografia encenada estaria precisamente nesse lugar onde o verdadeiro e o falso são indistintos. Ela se coloca "nessa situação onde o desconforto que [...] impõe à razão - do verdadeiro pois registrado, mas falso pois representado - não consegue ser resolvido" (POIVERT, 2015, p. 106).

Já para o filósofo e crítico da fotografia, François Soulages, não é apenas o estatuto da imagem que se transforma na cena contemporânea, mas o próprio papel do fotógrafo. Analisando os ensaios de diversos realizadores contemporâneos, Soulages afirma que 
o fotógrafo não pode mais ser visto como um caçador, um arqueiro-zen à espera do momento decisivo (do disparo certeiro), mas como homo faber, alguém que fabrica e constrói as imagens, que as recria em ato poético. Hoje, o fotógrafo estaria mais próximo da figura do diretor de cena, daquele que concebe e põe em jogo uma mise-en-scène, que encena e dirige atores num palco, tentando traduzir em imagem uma cena ou história previamente programada.

É o que faz o fotógrafo americano Duane Michals, certamente um dos precursores da fotografia encenada contemporânea. Nascido em 1932, Duane opta por forjar um estilo marcado pela narratividade através do uso de sequências de imagens que contam pequenas histórias ficcionais baseadas nas suas vivências e convicções. Em suas narrativas fotográficas, ele constrói discursos intimistas, encenações singulares sobre reflexões existenciais que engendram relações entre a vida e a arte. Assumindo total controle sobre sua produção, Duane estrutura sua obra a partir de alguns recursos cênicos que vão desde a produção de imagens em cenários predeterminados à utilização de modelos ensaiados como personagens. Revela, assim, sua face controladora como encenador que prevê, direciona, conduz. Organiza a mise-en-scène e manifesta seu estilo como criador sintonizado à proposta que Soulages estabelece para o fotógrafo: "Deus ordenador que introduz ordem no real que quer fotografar" (SOULAGES, 2010, p. 67).
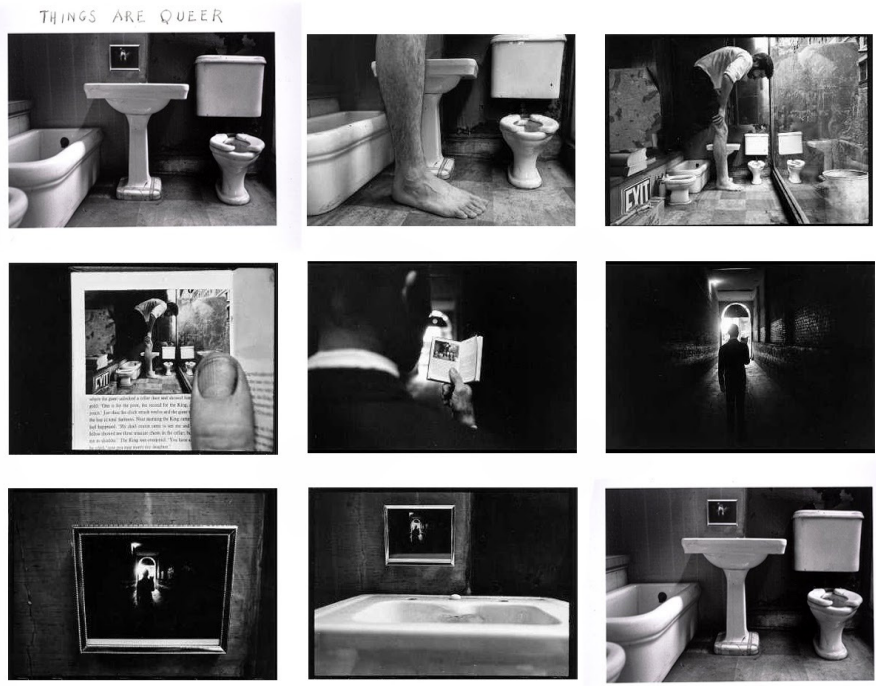

Fig. 4. Duane Michals. Things are queer, 1972. Fonte: https://www.sfmoma.org/artwork/84.58.B

Assim como Duane, fotógrafos como Sam Taylor-Wood, Delphine Balley, Dulce Pinzón, Gregory Crewdson, Liu Zheng, entre outros, afirmam o caráter artificial e criador 
da fotografia, se apresentando, antes de tudo, como encenadores - "deuses de um instante", segundo Soulages.

Para eles, mesmo a fotografia dita direta tem uma natureza teatral, na medida em que diante de um fotógrafo, o sujeito posaria duplamente: "pose fotográfica e afetação mundana, cultural e social" (SOULAGES, 2010, p. 71). Toda fotografia seria, então, construída a partir de uma encenação. Ela não se constituiria como prova do real, mas como uma relação de jogo, de tensão, de pulsões entre os seus dois pólos fundamentais. E, nesse jogo de construção imagética, "a ficção talvez seja o melhor meio de se compreender a realidade" (idem, p. 78). Pois oferece a possibilidade potencial não de reproduzí-la, mas de criticá-la criando novos mundos, outras percepções. Como afirma Rancière "fingere não quer dizer, em primeiro lugar, fingir, mas forjar" (2013, p. 160). Trata-se de um trabalho que muda as coordenadas do representável para que possamos melhor compreendê-lo, pensá-lo sob outros ângulos e, quem sabe assim, reinventá-lo.

Pois bem. Sabemos do caráter incompleto e puramente introdutório das reflexões que realizamos aqui. Acreditamos, contudo, que, apesar de Sontag (1983, p. 130) afirmar que "o conflito entre objetividade e subjetividade, entre demonstração e suposição é insolúvel", as imagens fotográficas retém muito mais do que coisas. É fato. O que restaria à fotografia contemporânea então? Jogar com as coisas, afirma Rouillé: "do ideal do verdadeiro e da proximidade aos jogos infinitos das interferências e das distâncias" (2009, p. 159). Jogos que extraem dessas imagens entidades imateriais, não existentes, que ele chama de eventos. Jogos "que têm levado a fotografia a um lugar limítrofe, a uma zona de indiscernibilidade entre linguagens, artes e saberes" (DOBAL; REIS FILHO, 2013, p. 72). É a encenação uma das possibilidades de estabelecer esse jogo.

Osmar Gonçalves é coordenador do Programa de Pósgraduação em Comunicação da Universidade Federal do Ceará e pós-doutor em Cinema e Arte Contemporânea pela Universidade Sorbonne-Nouvelle (Paris 3). É doutor em Comunicação pela Universidade Federal de Minas Gerais (2010). É um dos coordenadores do IMAGO - Laboratório de Estudos de Estética e Imagem (CNPq), do Seminário Temático Interseções Cinema e Arte, da SOCINE. Organizou os livros Narrativas sensoriais: ensaios sobre cinema e arte contemporânea (Circuito, 2014), ganhador do Prêmio FUNARTE de Estímulo à Produção Crítica em Artes Visuais. Junto com Susana Dobal organizou Fotografia contemporânea: fronteiras e transgressões (Casa das Musas, 2013).

osmargoncalves@hotmail.com 
Isabelle Freire de Morais é mestre em Comunicação pela Universidade Federal do Ceará, onde integra o Grupo de Pesquisa Vilém Flusser do Programa de Pós-Graduação em Comunicação. Como atriz, teve participação em mais de 18 espetáculos teatrais de 1997 a 2014, com os grupos Balaio, Expressões Humanas, Bagaceira e Capricórnio Produções, com premiações de destaque como atriz revelação (em 1998) e atriz coadjuvante (em 1999, 2002, 2006 e 2015). Como fotógrafa, participou das Mostras Coletivas "Mágica Imagem" (2012) e "Memória e Produção de Conhecimento" (de dezembro/12 a janeiro/13), promovidas pelos Encontros de Agosto no Museu da Cultura Cearense e no Centro Cultural Dragão do Mar, respectivamente. Contemplada no Edital Cultural 2015/2016 do Centro Cultural Dragão do Mar com o Projeto "Descartável" - Exposição Fotográfica e Performance de Intervenção em Espaços Externos, que aconteceu de dezembro/15 a fevereiro/16.

isabelledemorais@yahoo.com.br

\section{Referências}

AUMONT, J. O cinema e a encenação. Lisboa: Edições Texto \& Grafia Ltda, 2006.

BARTHES, R. A câmera clara: notas sobre a fotografia. Rio de Janeiro: Nova Fronteira, 1984.

BASTOS, M. T. F. Uma investigação na intimidade do portrait fotográfico. 2007. Tese de Doutorado. Pontifícia Universidade Católica. Rio de Janeiro. 244f.

BENJAMIN, W. Pequena história da fotografia. In: Obras escolhidas. Volume I. Magia e Técnica, Arte e Política. São Paulo: Brasiliense, 1987.

DOBAL, S.; REIS FILHO, O. Fotografia contemporânea: fronteiras e transgressões. Brasília: Casa das Musas, 2013.

DUBOIS, P. O ato fotográfico e outros ensaios. Campinas: Papirus, 1993.

ERTEM, F. The pose in early portrait photography: questioning attempts to appropriate the past. Image and narrative. [S.I]: Online Magazine of the visual narrative, Vol. VIII, issue 1, 2006. Disponível em: <http://www.imageandnarrative.be/inarchive/painting/fulya.htm>. Acesso em: 01 ago. 2013. Não paginado.

FABRIS, A. Fotografia: uso e funções no século XIX. São Paulo: Editora da Universiadade de São Paulo, 2008

Identidades virtuais: uma leitura do retrato fotográfico. Belo Horizonte: Editora UFMG, 2004.

O desafio do olhar: fotografia e artes visuais no período das vanguardas históricas. São Paulo: Editora WMF Martins Fortes: 2010.

FLUSSER, V. Filosofia da caixa preta: ensaios para uma filosofia da fotografia. São Paulo: Annablume, 2011. 
FONTCUBERTA, J. A câmera de Pandora: a fotografia depois da fotografia. São Paulo: Editora Gustavo Gili, 2010.

O beijo de Judas: fotografia e verdade. São Paulo: Editora Gustavo Gili, 2010.

HUIZINGA, Johan. Homo ludens: o jogo como elemento da cultura. São Paulo: Perspectiva, 1980.

LEHMANN, H-T. Teatro pós-dramático. São Paulo: Cosac \& Naify, 2007.

POIVERT, M. Notas sobre a imagem encenada, paradigma reprovado da história da fotografia? Trad. Fernanda Veríssimo. Disponível em: http://seer.ufrgs.br/index.php/PortoArte/article/ download/73716/41486. Último acesso maio de 2018.

RANCIÈRE, J. A partilha do sensível: estética e política. São Paulo: Ed. 34, 2005.

ROUILLÉ, A. A fotografia: entre o documento e a arte contemporânea. São Paulo: Editora SENAC, 2009.

SHUSTERMAN, R. Photography as performative process. [S.I.]: The journal of aesthetics and art criticism: the american society of aesthetics. 2012. P. 67-77. Disponível em: $<$ https://www.academia. edu/3125165/_Photography_as_Performative_Process_>. Acesso em: 12 dez. 2013.

SONTAG, S. Ensaios sobre fotografia. Rio de Janeiro: Arbor, 1983.

SOULAGES, F. Estética da fotografia: perda e permanência. São Paulo: Editora SENAC, 2010.

Artigo recebido em 21/03/2018

e aprovado em 13/06/2018. 